\title{
NON-SYMMETRIC STOLARSKY MEANS
}

\section{SaAd Ihsan Butt, Josip PeČArić AND ATIQ UR REHMAN}

Abstract. In this paper we construct $n$-exponentially convex functions and exponentially convex functions using the functional defined as the difference of the right parts of the HermiteHadamard inequality, for different classes of functions. Applying these results on some starshaped functions, we derive non-symmetric means of Stolarsky type.

Mathematics subject classification (2010): 26 D15.

Keywords and phrases: Convex function, log-convex functions, power sums, mean value theorems.

\section{REFERENCES}

[1] A. M. Bruckner, E. Ostrow, Some function classes related to the class of convex functions, Pacific J. Math., 12 (4) (1962), 1203-1215.

[2] A. M. Fink, D. S. Mitrinović And J. PEČArić, Classical and new inequalities in analysis, Kluwer Academic Publishers, The Netherlands, 1993.

[3] J. Jakšetić, J. PeČArić And Atiq UR Rehman, On Stolarsky and related means, Math. Inequal. Appl., 13 (4) (2010), 899-909.

[4] J. PEČARIĆ AND J. PERIĆ, Improvements of the Giaccardi and the Petrović inequalty and related Stolarsky type means, An. Univ. Craiova Ser. Mat. Inform. 39 (1) (2012), 65-75.

[5] J. Pečarić, F. Proschan and Y. L. Tong, Convex functions, Partial Orderings and Statistical Applications, vol. 187 of Mathematics in Science and Engineering, Academic Press, Boston, Mass, USA, 1992.

[6] K. B. Stolars Ky, Generalization of the logarithmic mean, Math. Mag., 48 (1975), 87-92.

[7] GH. ToAder, Superaddivtivity and Hermite-Hadamard's inequalites, Studia Univ. Babeş-Bolyai Math., 39 (1994), 27-32. 